\title{
Atypical furunculosis vaccines for Atlantic cod Gadhus morhua: impact of reattached Aeromonas salmonicida A-layer protein on vaccine efficacy
}

\author{
Vera Lund $^{1, *}$, Helene Mikkelsen ${ }^{1}$, Merete B. Schrøder ${ }^{2}$ \\ ${ }^{1}$ Nofima Marin, Norwegian Institute of Food Fisheries and Aquaculture Research, PO Box 6122, 9291 Tromsø, Norway \\ ${ }^{2}$ Norwegian College of Fishery Science, University of Tromsø, 9037 Tromsø, Norway
}

\begin{abstract}
Atypical furunculosis caused by atypical Aeromonas salmonicida bacteria is reported as an increasing problem in farmed Atlantic cod Gadus morhua in Norway. At present, furunculosis vaccines adapted for cod or other marine fish species are not available. To identify bacterial components important for inducing protection in cod, we compared oil-adjuvanted vaccines based on $A$. salmonicida isolates phenotypically differing in their major cell surface constituents, such as the Alayer protein and lipopolysaccharide O-chains. Also included was an A-layer-deficient isolate with physically reattached A-layer protein. Vaccines containing A. salmonicida A-layer-producing cells elicited significantly better protection than vaccines with A-layer-deficient cells or with a supernatant with secreted A-layer protein. The A. salmonicida cells with reattached A-layer-protein resulted in significant and equal protection to the A-layer-producing cells and protected significantly better than the A-layer-deficient isolate. These results indicate that the A-layer protein when attached to the cell surface plays a role in inducing protective immunity in cod.
\end{abstract}

KEY WORDS: Atlantic cod $\cdot$ Aeromonas salmonicida $\cdot$ Furunculosis $\cdot$ Vaccine $\cdot$ A-layer protein Resale or republication not permitted without written consent of the publishe

\section{INTRODUCTION}

Farming of Atlantic cod Gadus morhua is still in its infancy, but even so, bacterial diseases are registered as an increasing problem (Samuelsen et al. 2006). Vibriosis has been the major disease since cod farming started in Norway, but is now partly controlled by vaccines adapted to cod (Mikkelsen et al. 2007). Atypical furunculosis caused by atypical Aeromonas salmonicida has been the main problem in cod farming in Iceland (Magnadóttir et al. 2002) and is now being reported in increasing numbers of farms along the coast of Norway. Vaccines against atypical furunculosis in marine fish species are not available (Gudmundsdóttir \& Björnsdóttir 2007); however, a few reports exist on vaccination of cod. Vaccination, either with an oiladjuvanted commercial furunculosis vaccine or an experimental bacterin based on the challenge strain, did not elicit significant protection in cod against injection or bath challenge (Gudmundsdóttir et al. 2005, Gudmundsdóttir \& Björnsdóttir 2007). An experimental oil-adjuvanted furunculosis vaccine based on an atypical A. salmonicida isolate from cod elicited good protection against homologous injection challenge (Mikkelsen et al. 2004). Furthermore, this vaccine protected better than a commercial salmon furunculosis vaccine (Lund et al. 2008a), indicating that vaccines adapted for cod are needed.

Although the protective antigen(s) in typical or atypical furunculosis vaccines are still unclear, several candidates have been suggested. An extra-cellular metallo-protease (Gudmundsdóttir \& Magnadóttir 1997), a purified porin (Lutwyche et al. 1995) and both ironregulated outer-membrane proteins and extra-cellular polysaccharides (Hirst \& Ellis 1994, Bricknell et al. 1997, Bricknell et al. 1999) have all been correlated to 
protection in salmonids. Furthermore, a correlation between survival rates and corresponding antibody levels to the A-layer protein has been found in Atlantic salmon Salmo salar and goldfish Carassius auratus (Midtlyng et al. 1996, Sinyakov et al. 2002). Earlier studies have shown that A-layer-possessing Aeromonas salmonicida used in oil-adjuvanted vaccines elicit acceptable protection against homologous challenge in salmon, as well as in marine fish species. However, vaccines based on A-layer-deficient isolates failed to protect in salmon and protected poorly or not at all in cod and Atlantic halibut Hippoglossus hippoglossus (Lund et al. 2003a,b, Mikkelsen et al. 2004, Lund et al. 2008a,b).

Various A-layer functions have been identified by using A-layer-deficient mutants. In addition, physical reconstitution of the A-layer proved to be a useful tool in studying the functions of the Aeromonas salmonicida A-layer and identifying A-layer structurefunction relationships (Garduño et al. 1995). Mutations leading to lipopolysaccharide (LPS) O-chain-deficient strains gave rise to A-layer-deficient strains that released free sheets of assembled A-layer into the culture medium. This led to the assumption that LPS Ochains were involved in tethering the $A$. salmonicida A-layer to the bacterial outer membrane (Belland \& Trust 1985, Dooley et al. 1989). A. salmonicida strains lacking the A-layer, but possessing the LPS O-chain, rapidly absorbed secreted A-protein at the cell surface to coat the cells with a single confluent layer (Griffiths \& Lynch 1990). Physical reconstitution of the A-layer could be achieved by co-culturing A. salmonicida Alayer donor and receiver, or suspending A-layerdeficient cells in a supernatant from A-layer-secreting cells (Garduño et al. 1995). These cells recovered such functions as hydrophobicity, autoaggregation, porphyrin binding, adherence to and invasion of fish macrophages and resistance to macrophage cytotoxicity (Olivier et al. 1986, Garduño \& Kay 1992, Garduño et al. 1995, 2000, Daly et al. 1996.
The aim of the present study was to investigate the impact of reattached secreted A-layer protein of atypical Aeromonas salmonicida on vaccine efficacy in Atlantic cod.

\section{MATERIALS AND METHODS}

Fish. A total of 880 Atlantic cod were randomly selected from a mixture of 3000 fish originating from 10 families provided by the National Cod Breeding program at Nofima Marin, Tromsø, Norway, and used for vaccination (800 fish) and prechallenge (80 fish). The fish had a mean weight of $30 \mathrm{~g}$ (range 25 to $35 \mathrm{~g})$, were healthy and unvaccinated. The experiment was approved by the National Animal Research Authority in Norway. Prior to marking, vaccination and challenge the fish were anaesthetized with Metacainum (70 mg l-1, Norsk Medisinaldepot). Different groups were marked at the operculum with Visible Implant Fluorescent Elastomer (Northwest Marine Technology).

Bacterial isolates. Aeromonas salmonicida and Vibrio anguillarum isolates used in this study are listed in Table 1. Atypical A. salmonicida aAs 4099 and subsp. achromogenes Asa 4075, both isolated from cod, in addition to subsp. achromogenes type strain Asa 4036, are referred to as atypical, while subsp. salmonicida type strain Ass 4010 is referred to as typical. Both Ass 4010 and Asa 4036 are A-layerdeficient due to a deletion in the vapA gene encoding the A-protein (Lund \& Mikkelsen 2004). The Asa 4075 is O-chain negative and therefore secretes the A-protein to the culture medium. The vapA gene has been shown to possess a variable region that can be used for grouping of atypical isolates (Lund et al. 2003b). The strains aAs 4099 (GenBank accession number AJ749879), Asa 4036 (AJ49888) and Asa 4075 all group together (Lund \& Mikkelsen 2004, authors' unpubl. data).

Table 1. Aeromonas salmonicida and Vibrio anguillarum isolates used in this study. A: A-layer, O: polysaccharide O-chain

\begin{tabular}{|c|c|c|c|c|c|}
\hline Isolate no. & Subsp./serotype & Phenotype & Host & $\begin{array}{c}\text { Original } \\
\text { designation }\end{array}$ & Source \\
\hline \multicolumn{6}{|c|}{ A. salmonicida } \\
\hline $\begin{array}{l}\text { aAs } 4099 \\
\text { Asa } 4036\end{array}$ & $\begin{array}{l}\text { atypical } \\
\text { achromogenes }\end{array}$ & A-/O+ & Brook trout & 93/09/914 & $\begin{array}{l}\text { D. Corqunoun } \\
\text { ATCC } 33659\end{array}$ \\
\hline Asa 4075 & achromogenes & $\mathrm{A}+/ \mathrm{O}-$ & Atlantic cod & $\mathrm{T}-233 / 91$ & B. Gudmundsdóttir ${ }^{b}$ \\
\hline Ass 4010 & salmonicida & $\mathrm{A}-/ \mathrm{O}+$ & Atlantic salmon & & NCIMB 1102 \\
\hline \multicolumn{6}{|c|}{ V. anguillarum } \\
\hline Va 2129 & O1 & $\mathrm{O}+$ & Rainbow trout & & NCIMB 2129 \\
\hline Va 1282 & $\mathrm{O} 2$ & $\mathrm{O}+$ & Atlantic cod & & Lund et al. 2007 \\
\hline
\end{tabular}


The Aeromonas salmonicida LPS O-chain has been reported to differ between typical and atypical isolates. All typical isolates so far investigated produce a complete O-chain polysaccharide structure composed of a trisaccharide repeating unit. Atypical isolates, including aAs 4099 and Asa 4036, produce a disaccharide repeating unit (Wang et al. 2005, 2007).

Vibrio anguillarum isolates used were of serotype $\mathrm{O} 1$ (Va 2129), possessing high molecular weight O-chains of homogenous length (Knappskog et al. 1993) and serotype O2 (Va 1282) with O-chains of variable length (Lund et al. 2007).

Media and growth conditions. Bacterial isolates stored in glycerol at $-80^{\circ} \mathrm{C}$ were inoculated on Tryptic Soya Agar (Oxoid) supplemented with 5\% human blood and $1.5 \% \mathrm{NaCl}$ (BA plate) and incubated for $3 \mathrm{~d}$ at $12^{\circ} \mathrm{C}$. Aeromonas salmonicida was grown in brain heart infusion broth (BHI, Difco) and Vibrio anguillarum in marine broth (MB-2216, Difco) at $12^{\circ} \mathrm{C}$ for 24 to $30 \mathrm{~h}$ until an optical density at $600 \mathrm{~nm}\left(\mathrm{OD}_{600 \mathrm{~nm}}\right)$ of approximately 1.0. The bacterial cultures were either used for challenge and attachment of A-layer protein or inactivated by adding formaldehyde solution (37\%) to a final concentration of $0.5 \%(\mathrm{v} / \mathrm{v})$, before being used as vaccines or as antigens on Western blot. BA plates were used to determine cfu of challenge doses. BHI agar supplemented with $2 \% \mathrm{NaCl}$ and $0.005 \%$ Coomassie Brilliant Blue R (Sigma) (BHI-CBB plates) was used for re-isolation of $A$. salmonicida from moribund fish. Growth of A. salmonicida was confirmed by Mono-As agglutination test (Bio-Nor)

Electrophoresis and Western blotting. Aeromonas salmonicida isolates were characterised by sodium dodecyl sulphate-polyacrylamid gel electrophoresis (SDS-PAGE) and Western blotting using the Bio-Rad Criterion system including premixed running buffer and XT MOPS sample buffer with reducing agents (Lund et al. 2006). Briefly, lysates of bacterial cells or supernatants were separated in $12 \%$ Bis-Tris gels (Bio-Rad), transferred onto $0.45 \mu \mathrm{m}$ nitrocellulose membranes that were subsequently blocked for $2 \mathrm{~h}$ with $5 \%$ skimmed milk (Molico Instant, Nestle) in phosphate buffered saline (PBS) with $0.05 \%$ Tween 20 . A rabbit $A$. salmonicida A-protein (R- $\alpha-\mathrm{A})$ antiserum produced in our laboratory and a mouse monoclonal antibody (mAb) with specificity to the LPS O-chain (mAb 2E6) (Björnsdóttir et al. 1992) were used to identify the A-protein and LPS O-chains in the A. salmonicida isolates. Bound antibodies were detected with goat-anti-rabbit Ig conjugated with alkaline phosphatase
(DakoCytomation) or goat-anti-mouse Ig conjugated with alkaline phosphatase (Sigma). Finally, the membranes were incubated for 5 min with substrates nitroblue tetrazolium chloride (NBT) and 5-bromo4-chloro-3-indolylphosphate (BCIP) (Promega) in substrate buffer $(0.1 \mathrm{M}$ Tris $\mathrm{pH} 9.5,0.1 \mathrm{M} \mathrm{NaCl}$ and $50 \mathrm{mM} \mathrm{MgCl}_{2}$ ). Gels were protein stained with coomassie (Imperial ${ }^{\mathrm{TM}}$ Protein Stain, Pierce) and SDSPAGE Standard Broad Range and Precision Plus Protein Standard All Blue (Bio-Rad) were used as molecular weight markers on gel and blot, respectively.

Attachment of A-layer protein to bacterial cells. Aeromonas salmonicida and Vibrio anguillarum cultures were centrifuged at 4000 and $8000 \times g$, respectively, and the cell pellet was suspended in the supernatant of the A-layer protein secreting Asa 4075 and incubated with gentle shaking for $30 \mathrm{~min}$ at $12^{\circ} \mathrm{C}$. The cells were washed in $10 \mathrm{mM}$ Tris $\mathrm{HCl} \mathrm{pH} 8.0$ before cell lysates were separated by SDS-PAGE and analysed on coomassie stained gels. In order to investigate whether the A-layer was firmly attached to the $A$. salmonicida surface, the cells were washed 5 times in $10 \mathrm{mM}$ Tris $\mathrm{HCl} \mathrm{pH}$ 8.0. After each washing cells were analysed on a coomassie stained gel.

Vaccine formulation. All vaccines were oil-adjuvanted using the same mineral oil as used in ALPHA JECT vaccines (PHARMAQ AS). The vaccines were made based on bacterin (B), i.e. formalin inactivated culture, bacterial cells (C) washed once in saline after centrifugation or supernatant (S) containing secreted A-layer protein (Table 2). B and $\mathrm{C}$ vaccines contained $10^{9}$ cells $\mathrm{ml}^{-1}$. The bacterial pellet was re-suspended in saline or supernatant to the appropriate concentration, whereby $\mathrm{OD}_{600 \mathrm{~nm}}=1$ corresponds to approximately $10^{9}$ cells $\mathrm{ml}^{-1}$. Vaccine $4036(\mathrm{~A}+)-\mathrm{C}$ was prepared by suspending the washed Asa 4036(A-) cell pellet in Asa 4075 supernatant $\left(\mathrm{OD}_{600 \mathrm{~nm}}=1\right)$. The mixture was incubated for 30 min with gentle shaking before being inactivated as described above and emulsified with the

Table 2. Gadus morhua vaccinated with oil-adjuvanted vaccines and intraperitoneal (ip) challenged with Aeromonas salmonicida aAs 4099. Vaccines are named according to the isolate number. The control group received saline without oil. Relative percent survival (RPS) calculated for each group (Gr.) as average in 2 tanks. Average mortality in control groups was $82 \%$ (see Fig. 4)

\begin{tabular}{|lllc|}
\hline Gr. & Vaccine & Vaccine antigen & RPS \\
\hline 1 & $4099-\mathrm{C}$ & aAs 4099 cells & 78 \\
2 & $4099-\mathrm{B}$ & aAs 4099 bacterin & 73 \\
3 & $4036(\mathrm{~A}-)-\mathrm{C}$ & Asa 4036 cells & 35 \\
4 & $4036(\mathrm{~A}+)-\mathrm{C}$ & Asa 4036 cells with reattached Asa 4075 A-protein & 76 \\
5 & $4075-\mathrm{C}$ & Asa 4075 cells & 36 \\
6 & $4075-\mathrm{B}$ & Asa 4075 bacterin & 39 \\
7 & $4075-\mathrm{S}$ & Asa 4075 supernatant with secreted A-protein & 35 \\
8 & Saline & Saline & \\
\hline
\end{tabular}


oil adjuvant. Vaccine 4075-S contained supernatant (total protein $3.2 \mathrm{mg} \mathrm{ml}^{-1}$ ) emulsified in oil adjuvant.

Vaccination and challenge. Seven groups of 100 fish were vaccinated by intraperitoneal (ip) injection of $0.1 \mathrm{ml}$ vaccine fish $^{-1}$ (Table 2). The control group received $0.1 \mathrm{ml}$ saline fish $^{-1}$. The groups were kept in separate tanks (500 l) at $10^{\circ} \mathrm{C}$ for 7 wk. Five days prior to challenge the 8 groups were distributed as follows; 50 fish from each group were placed into duplicate tanks resulting in a total of 400 fish in each tank (900 l).

Prechallenge and challenge were performed at $12^{\circ} \mathrm{C}$. Prechallenge was performed 3 wk prior to challenge of vaccinated fish in order to determine the dose of aAs 4099 ( $\mathrm{cfu} \mathrm{fish}^{-1}$ ) needed to obtain 60 to $90 \%$ mortality in an unvaccinated control group. Three groups of 20 fish were marked before receiving $0.1 \mathrm{ml}$ doses of 10-fold dilutions of an aAs 4099 culture and transferred to a $500 \mathrm{l}$ tank. In addition a control group of 20 fish injected with $0.1 \mathrm{ml}$ saline was included. The exact dose was determined by plating on BA-plates. Doses of $7.3 \times 10^{5}, 7.3 \times 10^{4}$ and $7.3 \times 10^{3} \mathrm{cfu}^{\mathrm{fish}}{ }^{-1}$ resulted in 100, 45 and $31 \%$ cumulative mortality, respectively.

The vaccinated groups were challenged in parallel tanks by ip injection of $0.1 \mathrm{ml}$ fish $^{-1}$ of a bacterial dilution containing $1.6 \times 10^{5} \mathrm{cfu}$ of aAs 4099. Dead and moribund fish were recorded and removed daily. Cause of death was verified by re-isolation of Aeromonas salmonicida from head kidney seen as blue colonies on BHI-CBB plates. Relative percent survival (RPS) was calculated according to the method of Amend (1981).

Statistical analysis. Logistic regression (Type III sum of squares) in the GENMOD procedure of SAS 9.1.3
(SAS 1993) was used to determine statistical differences in mortality between duplicate tanks and between the vaccinated and unvaccinated groups. Comparison of the vaccines was based on the results from duplicate tanks and each vaccine was compared to the others one by one. The results were considered significant for $\mathrm{p}<0.05$.

\section{RESULTS}

Aeromonas salmonicida isolates (Table 1) used as vaccines and the additional isolate Ass 4010 were characterised by SDS-PAGE and Western blotting (Fig. 1). Protein staining of the gel indicated that only the aAs 4099 cells and the Asa 4075 supernatant contained a major protein of $50 \mathrm{kDa}$ (Fig. 1A), confirmed to be the A-layer protein by the R- $\alpha$-A serum by Western blot (Fig. 1B,C). All A. salmonicida isolates except Asa 4075 contained high molecular weight O-chains as identified by the LPS O-chain specific mAb 2E6 (Fig. 1D). Only the Asa 4036 supernatant contained considerable amounts of O-chains (Fig. 1E), and only the LPS O-chain-negative Asa 4075 secreted A-protein into the culture supernatant (Fig. 1C). Hereafter, the A. salmonicida isolates are referred to as aAs 4099 A+/O+, Asa 4036 A-/O+, Asa 4075 A+/O- and Ass $4010 \mathrm{~A}-/ \mathrm{O}+$.

Specificity of the attachment of the A-layer protein was investigated by mixing the A-protein-secreting Asa 4075 supernatant with O-polysaccharide possessing Aeromonas salmonicida and Vibrio anguillarum cells. The A-layer protein was shown to attach to cells of both the typical Ass $4010 \mathrm{~A}-/ \mathrm{O}+$ and atypical Asa
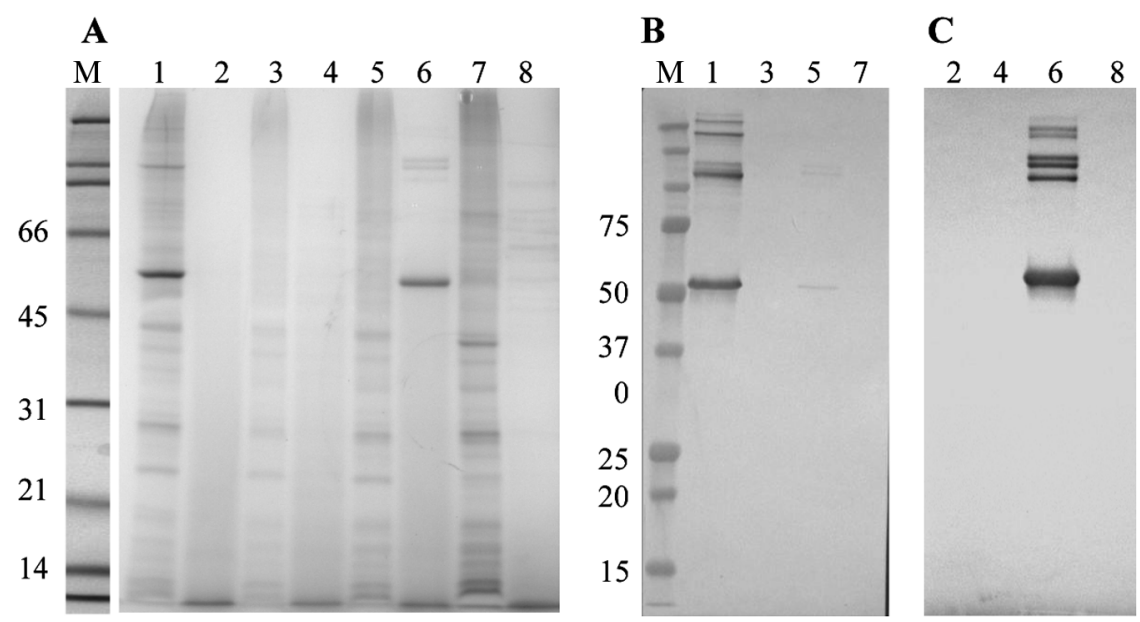

D

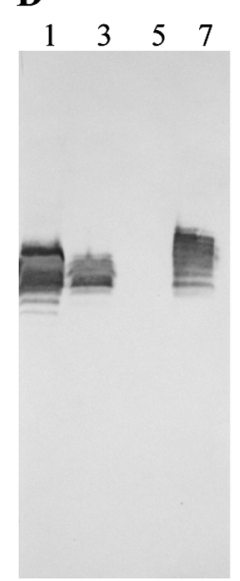

$\mathbf{E}$

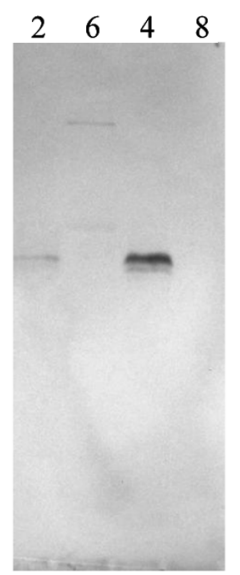

Fig. 1. Aeromonas salmonicida isolates characterised by SDS-PAGE and Western blot. (A) Coomassie staining of gel with cell lysates and supernatants. Western blot with (B) cell lysates, (C) supernatants stained with R- $\alpha$-A serum, (D) cell lysates and (E) supernatants stained with lipopolysaccharide (LPS) O-chain-specific mAb 2E6. Lanes: 1, Asa 4099 cells; 2, Asa 4099 supernatant; 3 , Asa 4036 cells; 4, Asa 4036 supernatant; 5, Asa 4075 cells; 6, Asa 4075 supernatant; 7, Ass 4010 cells; 8, Ass 4010 supernatant. Molecular weight marker $(\mathrm{M})$ indicated in $\mathrm{kDa}$ 


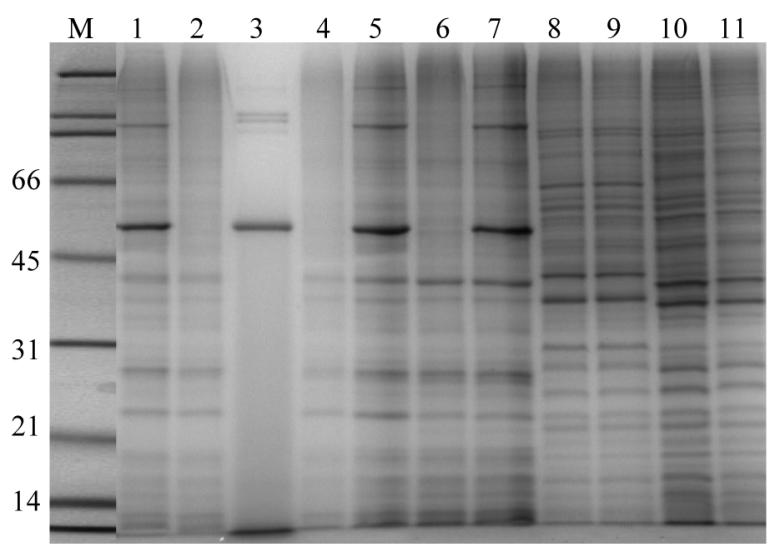

Fig. 2. Aeromonas salmonicida and Vibrio anguillarum. Reattachment of A-layer protein to bacterial cells analysed on Coomassie-stained gel. Lanes: 1, aAs 4099 cells; 2, Asa 4075 cells; 3, Asa 4075 supernatant; 4, Asa 4036 cells; 5, Asa 4036 with Asa 4075 supernatant; 6, Ass 4010 cells; 7, Ass 4010 cells incubated with Asa 4075 supernatant; 8, Va 2129 cells; 9, Va 2129 cells incubated with Asa 4075 supernatant; 10, Va 1282 cells; 11, Va 1282 cells incubated with Asa 4075 supernatant. Molecular weight marker $(\mathrm{M})$ indicated in $\mathrm{kDa}$

4036 A-/O+ isolates, but not to O-polysaccharide possessing $V$. anguillarum serotype $\mathrm{O} 1$ or $\mathrm{O} 2$ (Fig. 2). Repeated washing, up to 5 times, of the Asa 4036 cells did not remove the A-layer protein that was firmly attached to the cell surface (Fig. 3).

Protection elicited in Atlantic cod by vaccines based on Aeromonas salmonicida isolates possessing or lacking the A-layer protein and/or the O-chains, or an isolate with reattached A-layer protein, was compared in duplicate tanks when ip challenged with the aAs $4099 \mathrm{~A}+/ \mathrm{O}+$ isolate (Table 2). The results are presented as average RPS (Table 2) and as cumulative mortality (\%) in each group in duplicate tanks (Fig. 4).

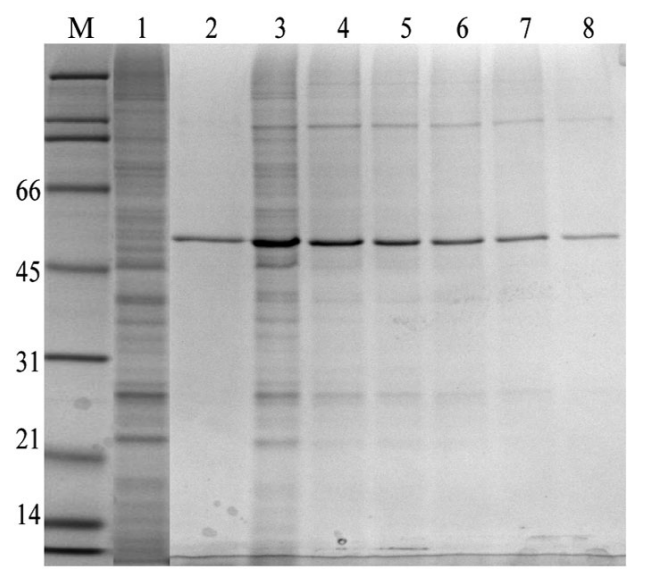

Fig. 3. Aeromonas salmonicida cells with reattached A-layer protein washed up to $5 \times$ and analysed on Coomassie-stained gel after each wash. Lanes: 1, Asa 4036 (A-); 2, Asa 4075 supernatant; 3, Asa 4036 incubated with Asa 4075 supernatant; 4 to 8 , Asa 4036 with reattached A-layer protein after 1 to 5 washings. Molecular weight marker (M) indicated in $\mathrm{kDa}$

Total cumulative mortality did not differ between the tanks $(\mathrm{p}=0.0852)$. The vaccine based on aAs 4099 A+/O+ cells (4099-C) or bacterin (4099-B) did not differ significantly. Furthermore, the vaccine based on Asa $4036 \mathrm{~A}-/ \mathrm{O}+$ cells with reattached A-layer protein, 4036(A+)-C did not differ from the 4099-C vaccine, while vaccines 4036(A-)-C and 4075-C with A-layerdeficient cells, or vaccine 4075-S containing supernatant with secreted A-layer protein, protected significantly less. Compared to the control group, all vaccines elicited significant protection (Table 2), but vaccines based on A. salmonicida A+/O+ cells elicited equal and significantly better protection (RPS 73 to 78) than vaccines based on $\mathrm{A}-/ \mathrm{O}+$ or $\mathrm{A}-/ \mathrm{O}-$ cells or on $\mathrm{A}+$ supernatant (RPS 35 to 39).

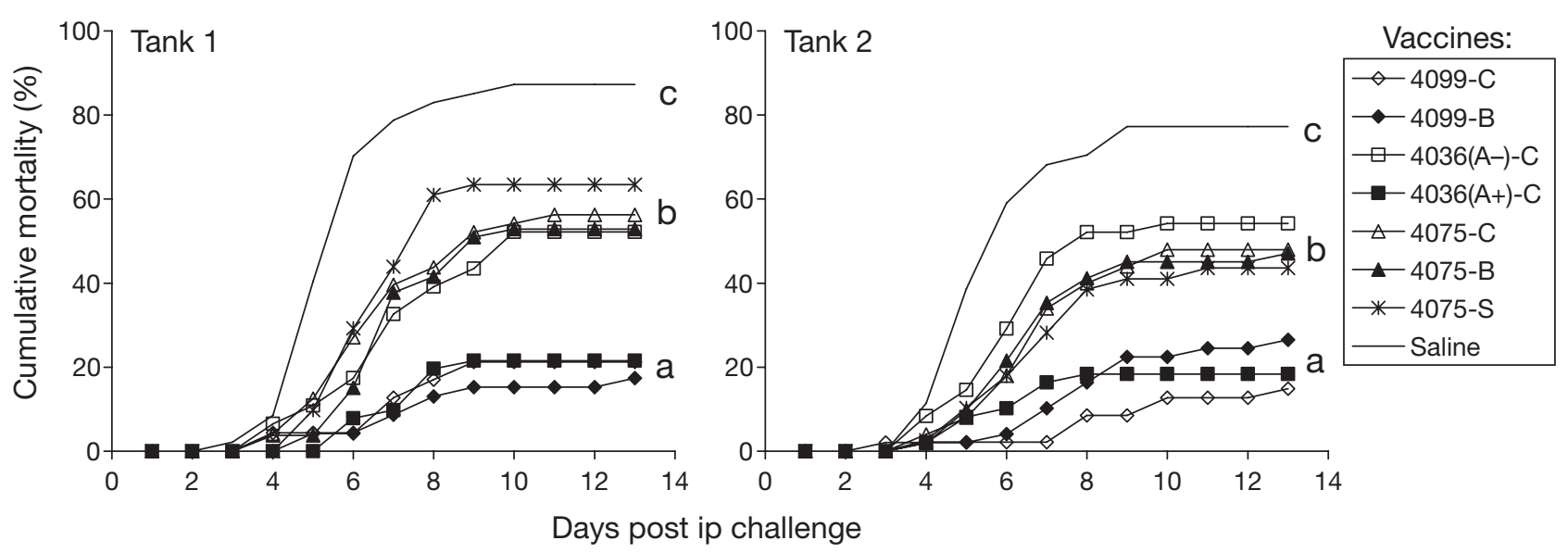

Fig. 4. Gadus morhua vaccinated with furunculosis vaccines (see Table 2). Cumulative mortality (\%) in groups post intraperitoneal (ip) challenge with atypical Aeromonas salmonicida aAs $4099\left(1.6 \times 10^{5} \mathrm{cfu}_{\mathrm{fish}}^{-1}\right)$ in 2 separate tanks. Significant differences in mortality between groups are indicated with different letters 


\section{DISCUSSION}

Physical reconstitution of the Aeromonas salmonicida A-layer has demonstrated recovered functions absent from A-layer-deficient mutants such as hydrophobicity, autoaggregation, adherence to fish cell lines and survival in head kidney macrophages (Garduño et al. 1995, 2000). In the present study we have used the same approach to investigate the importance of the A. salmonicida A-layer for protection in furunculosis vaccines for Atlantic cod. Ideally, A. salmonicida strains with a genetically reconstituted A-layer should be used, but as such were not available, A-layer protein was physically reattached to an A-layerdeficient isolate.

The Aeromonas salmonicida A-layer forms a complex structure partly embedded in the O-polysaccharide chains of homogenous length (Chart et al. 1984), of which only a portion penetrate the A-layer becoming accessible at the cell surface. Both the A-protein (Lund \& Mikkelsen 2004) and O-polysaccharide (Wang et al. 2007) have been shown to vary between typical and atypical $A$. salmonicida isolates, giving rise to putative variation in surface determinants between the isolates. In the present study A-layer protein secreted by Asa 4075 and genetically identical to that of the challenge isolate aAs 4099 (authors' unpubl. data) was attached to Asa $4036 \mathrm{~A}-/ \mathrm{O}+$ cells producing the same O-chain type as aAs 4099 (Wang et al. 2007). Therefore, the 4099-C and 4036(A+)-C vaccines should be comparable with regard to the A-protein and O-chain. These were shown to protect equally well and significantly better than the A-layer-deficient vaccines 4036(A-)-C and 4075-C, against challenge with aAs 4099. The A-layer-deficient Asa 4036 has been shown to be non-virulent (authors' unpubl. data) and could not be used for challenge.

Interestingly, supernatant with A-layer protein as the major component protected poorly, as did a vaccine based on purified A-protein in a previous study (Lund et al. 2008a). Mixing of Asa 4036 A-/O+ cells with Asa $4075 \mathrm{~A}+$ supernatant resulted in cells with reattached A-layer protein that elicited protection. Together with previous results that Aeromonas salmonicida $\mathrm{A}+\mathrm{O}+$ isolates elicited acceptable protection against homologous challenge while A-layer-deficient isolates failed to protect (Lund et al. 2003a,b, 2008a,b, Mikkelsen et al. 2004), this seems to indicate that the reattached A-layer protein is contributing to protection. Hence, the present result supports previous observations indicating that properties associated with the A-layer are regained in cells with a reconstituted A-layer (Garduño et al. 1995). Furthermore, electron microscopy revealed that the Asa 4036 cells with reattached A-layer protein had regained autoaggregating properties (not shown).
All vaccines elicited significant protection compared to the control group that was injected with saline only. However, vaccines based on Aeromonas salmonicida $\mathrm{A}+/ \mathrm{O}+$ cells elicited significantly better protection than the other vaccines containing $\mathrm{A}-/ \mathrm{O}+$ and $\mathrm{A}-/ \mathrm{O}-$ cells or A-protein containing supernatant. A control group injected with saline in oil adjuvant was not included in this study. This could have revealed whether bacterial components or a non-specific effect of the oil adjuvant were responsible for protection obtained with A-layerdeficient cells. Saline in Freund's Incomplete Adjuvant has been shown to protect cod significantly against ip challenge with aAs 4099 when compared to saline alone (Mikkelsen et al. 2004).

Rough mutants of Aeromonas salmonicida lacking the O-polysaccharide chain have been shown by electron microscopy to release large sheets of arrayed layers (Belland \& Trust 1985, Dooley et al. 1989) or Aprotein tetrameric units (Griffiths \& Lynch 1990) into the culture medium. As it is not known if the Asa 4075 $\mathrm{A}+/ \mathrm{O}-$ isolate used in this study secreted preformed A-layer sheets or tetrameric units resulting in reconstitution of a confluent surface A-layer, it appears more accurate to refer to $A$. salmonicida cells with reattached A-layer protein rather than a reconstituted A-layer.

Repeated washing did not remove the A-layer protein from the cells, suggesting that it is firmly attached to the cell surface. The apparent decrease in amount of A-protein after each washing step is more likely due to loss of cells during repeated centrifugation rather than the loss of A-protein from the cell surface. Indeed, all protein bands appeared to fade between each washing step. A specific high affinity binding interaction between A-protein and the O-polysaccharide chain of Aeromonas salmonicida cells was demonstrated, as the A-layer protein did not associate with the cell surface of unrelated gram-negative bacteria (Griffiths \& Lynch 1990, Garduño et al. 1995). Similarly, in the present study the A-layer protein did not associate with Vibrio anguillarum serotypes with high molecular weight $\mathrm{O}$ chains. Interestingly, although the O-polysaccharides of typical and atypical A. salmonicida represents distinct structural types composed of trisaccharide or disaccharide repeating units, respectively (Wang et al. 2007), the A-layer protein appeared to reattach onto both typical and atypical A-/O+ cells. This may result in differences in surface topography and antigenic determinants and may have impact on vaccine efficacy, which should be further assessed.

The reason the A-layer protein appears protective on the cell surface and not in solution may be that protective epitopes are recovered either as sole A-layer protein epitopes in correct conformation guided by the $\mathrm{O}$-chains or in combination with the O-chains or with 
other membrane components. Both a dissociable interaction between A-protein subunits and the O-polysaccharide chains (Garduño et al. 1995) and a tight interaction with outer membrane proteins, probably a porin, have been suggested (Garduño et al. 1994).

In summary, the present study confirms previous results that vaccines based on Aeromonas salmonicida A-layer-possessing isolates elicit significantly better protection in cod than a vaccine based on an A-layerdeficient isolate. Reattachment of the A-layer protein on an A-layer-deficient isolate was performed in order to produce A. salmonicida cells with A-layer protein and an O-polysaccharide chain structure comparable to the challenge isolate. Such cells elicited significant and equal protection to that seen with the homologous vaccine. These results indicate that the A-layer protein is important for achieving protection. Physical reattachment of A-layer sheets or purified A-protein should prove useful in elucidating the role of the A-layer in inducing protection in various farmed fish species.

Acknowledgements. This work was financially supported by The Research Council of Norway and the University of Tromsø, College of Fishery Science. We thank C. Maira, PHARMAQ AS, for providing the oil adjuvant, and $T$. Ellingsen and the personnel at the Aquaculture Research Station, Tromsø, for assistance with the fish experiment. We are grateful to M. Cooper, Nofima Marin, for reviewing the English.

\section{LITERATURE CITED}

Amend DF (1981) Potency testing of fish vaccines. In: Anderson DP, Hennessen W (eds) Fish biologics: serodiagnostics and vaccines. Karger, Basel, p 447-454

Belland RJ, Trust TJ (1985) Synthesis, export, and assembly of Aeromonas salmonicida A-layer analyzed by transposon mutagenesis. J Bacteriol 163:877-881

Björnsdóttir R, Eggset G, Nilsen R, Jørgensen TØ (1992) The A-layer protein of Aeromonas salmonicida: further characterization and a new isolation procedure. J Fish Dis 15:105-118

Bricknell IR, Bowden TJ, Lomax J, Ellis AE (1997) Antibody response and protection of Atlantic salmon (Salmo salar) immunised with an extracellular polysaccharide of Aeromonas salmonicida. Fish Shellfish Immunol 7:1-16

Bricknell IR, King JA, Bowden TJ, Ellis AE (1999) Duration of protective antibodies, and the correlation with protection in Atlantic salmon (Salmo salar L.), following vaccination with an Aeromonas salmonicida vaccine containing ironregulated outer membrane proteins and secretory polysaccharide. Fish Shellfish Immunol 9:139-151

Chart H, Shaw DH, Ishiguro EE, Trust TJ (1984) Structural and immunochemical homogeneity of Aeromonas salmonicida lipopolysaccharide. J Bacteriol 158:16-22

Daly JG, Kew AK, Moore AR, Olivier G (1996) The cell surface of Aeromonas salmonicida determines in vitro survival in cultured brook trout (Salvelinus fontinalis) peritoneal macrophages. Microb Pathog 21:447-461

Dooley JSG, Engelhardt H, Baumeister W, Kay WW, Trust TJ (1989) Three-dimensional structure of an open form of the surface layer from the fish pathogen Aeromonas salmonicida. J Bacteriol 171:190-197

Garduño RA, Kay WW (1992) Interaction of the fish pathogen Aeromonas salmonicida with rainbow trout macrophages. Infect Immun 60:4612-4620

Garduño RA, Phipps BM, Kay WW (1994) Physiological consequences of the S-layer of Aeromonas salmonicida in relation to growth, temperature, and outer membrane permeation. Can J Microbiol 40:622-629

Garduño RA, Phipps BM, Kay WW (1995) Physical and functional S-layer reconstitution in Aeromonas salmonicida. J Bacteriol 177:2684-2694

Garduño RA, Moore AR, Olivier G, Lizama AL, Garduno E, Kay WW (2000) Host cell invasion and intracellular residence by Aeromonas salmonicida: role of the S-layer. Can J Microbiol 46:660-668

Griffiths SG, Lynch WH (1990) Characterization of Aeromonas salmonicida variants with altered cell surfaces and their use in studying surface protein assembly. Arch Microbiol 154:308-312

Gudmundsdóttir BK, Björnsdóttir B (2007) Vaccination against atypical furunculosis and winter ulcer disease of fish. Vaccine 25:5512-5523

Gudmundsdóttir BK, Magnadóttir B (1997) Protection of Atlantic salmon (Salmo salar L.) against an experimental infection of Aeromonas salmonicida ssp. achromogenes. Fish Shellfish Immunol 7:55-69

Gudmundsdóttir BK, Björnsdóttir B, Arnadóttir H, Adalbjarnardóttir A, Magnadóttir B, Gudmundsdóttir S (2005) Experimental vaccination of cod against atypical furunculosis. In: Proc Euro Assoc Fish Pathologist, 12th Int Conf Fish Shellfish Dis, Copenhagen, p 104

Hirst ID, Ellis AE (1994) Iron-regulated outer membrane proteins of Aeromonas salmonicida are important protective antigens in Atlantic salmon against furunculosis. Fish Shellfish Immunol 4:29-45

> Knappskog DH, Rødseth OM, Endresen C (1993) Immunochemical analyses of Vibrio anguillarum strains isolated from cod, Gadus morhua L., suffering from vibriosis. J Fish Dis 16:327-338

> Lund V, Mikkelsen H (2004) Genetic diversity among Aproteins of atypical strains of Aeromonas salmonicida. Dis Aquat Org 61:257-262

Lund V, Arnesen JA, Coucheron D, Modalsli K, Syvertsen C (2003a) The Aeromonas salmonicida A-layer protein is an important protective antigen in oil-adjuvanted vaccines. Fish Shellfish Immunol 15:367-372

> Lund V, Espelid S, Mikkelsen H (2003b) Vaccine efficacy in spotted wolffish Anarhichas minor: relationship to molecular variation in A-layer protein of atypical Aeromonas salmonicida. Dis Aquat Org 56:31-42

> Lund V, Børdal S, Kjellsen O, Mikkelsen H, Schrøder MB (2006) Comparison of antibody responses in Atlantic cod (Gadus morhua L.) to Aeromonas salmonicida and Vibrio anguillarum. Dev Comp Immunol 30:1145-1155

Lund V, Børdal S, Schrøder MB (2007) Specificity and durability of antibody responses in Atlantic cod (Gadus morhua L.) immunised with Vibrio anguillarum O2b. Fish Shellfish Immunol 23:906-910

Lund V, Arnesen JA, Mikkelsen H, Gravningen K, Brown LL, Schrøder MB (2008a) Atypical furunculosis vaccines for Atlantic cod (Gadus morhua); vaccine efficacy and antibody responses. Vaccine 26(52):6791-6799

> Lund V, Mikkelsen H, Schrøder MB (2008b) Comparison of atypical furunculosis vaccines in spotted wolffish (Anarhichas minor O.) and Atlantic halibut (Hippoglossus hippoglossus L.). Vaccine 26:2833-2840 
Lutwyche P, Exner MM, Hancock REW, Trust TJ (1995) A conserved Aeromonas salmonicida porin provides protective immunity to rainbow trout. Infect Immun 63: 3137-3142

Magnadóttir B, Bambir SH, Gudmundsdóttir BK, Pilström L, Helgason S (2002) Atypical Aeromonas salmonicida infection in naturally and experimentally infected cod, Gadus morhua L. J Fish Dis 25:583-597

Midtlyng PJ, Reitan LJ, Speilberg L (1996) Experimental studies on the efficacy and the side-effects of intraperitoneal vaccination of Atlantic salmon (Salmon salar L.) against furunculosis. Fish Shellfish Immunol 6:335-350

Mikkelsen H, Schrøder MB, Lund V (2004) Vibriosis and atypical furunculosis vaccines; efficacy, specificity and side effects in Atlantic cod, Gadus morhua L. Aquaculture 242: 81-91

Mikkelsen H, Lund V, Martinsen LC, Gravningen K, Schrøder MB (2007) Variability among Vibrio anguillarum $\mathrm{O}_{2}$ isolates from Atlantic cod (Gadus morhua L.): characterisation and vaccination studies. Aquaculture 266:16-25

Olivier G, Eaton CA, Campell N (1986) Interaction between Aeromonas salmonicida and peritoneal macrophages of

Editorial responsibility: David Bruno,

Aberdeen, UK brook trout (Salvelinus fontinalis). Vet Immunol Immunopathol 12:223-234

Samuelsen OB, Nerland AH, Jørgensen TØ, Schrøder MB, Svåsand T, Bergh $\varnothing$ (2006) Viral and bacterial diseases of Atlantic cod Gadus morhua, their prophylaxis and treatment: a review. Dis Aquat Org 71:239-254

SAS (1993) SAS technical report P-243 SAS/STAT software: the GENMOD procedure, Release 9.1.3. SAS Institute, Cary, NC

Sinyakov MS, Dror M, Zhevelev HM, Marge S, Avatalion RR (2002) Natural antibodies and their significance in active immunization and protection against a defined pathogen in fish. Vaccine 20:3668-3674

Wang Z, Vinogradov E, Larocque S, Harrison BA, Li J, Altman E (2005) Structural and serological characterization of the O-chain polysaccharide of Aeromonas salmonicida strains A449, 80204 and 80204-1. Carbohydr Res 340:693-700

- Wang Z, Liu X, Dacanay A, Harrison BA and others (2007) Carbohydrate analysis and serological classification of typical and atypical isolates of Aeromonas salmonicida: a rationale for the lipopolysaccharide-based classification of A. salmonicida. Fish Shellfish Immunol 23:1095-1106

Submitted: November 11, 2008; Accepted: April 15, 2009 Proofs received from author(s): June 4, 2009 